\title{
Cloning of a novel gene from Penicillium oxalicum I1 which in Escherichia coli enhances the secretion of acetic acid
}

\author{
Liu Xue ${ }^{(1,3)}$, Zhu Chang-xiong ${ }^{(1)}$, Gong Ming-bo ${ }^{(2)}$
}

(1) Chinese Academy of Agricultural Sciences. Institute of Environment and Sustainable Development in Agriculture. Beijing 100081 (P.R. China).

(2) Chinese Academy of Agricultural Sciences. Key Laboratory of Microbial Resources. Ministry of Agriculture / Institute of Agricultural Resources and Regional Planning. Beijing 100081 (P.R. China). E-mail: gongcaas@163.com

(3) Université de Liège - Gembloux Agro-Bio Tech. Microbial Processes and Interactions(MiPI). Passage des Déportés, 2. BE-5030 Gembloux (Belgium).

Received 5 May 2017, accepted 4 December 2017, available online 6 February 2018.

This article is distributed under the terms and conditions of the CC-BY License (http://creativecommons.org/licenses/by/4.0)

Description of the subject. Organic acids play an important role in the conversion of insoluble ions into soluble ones in soil. Heterologous overexpression of a single gene in a cell is the optimal strategy for increasing the secretion of organic acids solubilizing phosphate.

Objectives. In this study, we constructed a primary cDNA library of Penicillium oxalicum I1, and screened clones that can solubilize P in tricalcium phosphate (TCP) medium. We aimed to obtain the gene expressed in Escherichia coli, which can enhance organic acid secretion.

Method. A primary cDNA library of Penicillium oxalicum I1 was constructed using the switching mechanism at the 5'-end of RNA transcription. The organic acid secretion ability of E. coli DH5 $\alpha^{\mathrm{TM}}$ with overexpressed P. oxalicum I1gene was tested in TCP medium where glucose is the sole carbon source. Afterwards, pyruvic acid, citric acid, $\alpha$-ketoglutaric acid, succinic acid, fumaric acid, and malic acid were used as sole carbon source substitutes for glucose in the TCP medium to test the organic acid secretion ability of the transformed E. coli $\mathrm{DH} 5 \alpha^{\mathrm{TM}}$.

Results. A total of 106 clones showed halos in TCP medium, among which clone I-2 displayed clear halo. The full-length cDNA of clone I-2 was $1,151 \mathrm{bp}$, with a complete open reading frame of $702 \mathrm{bp}$, which encoded a hypothetical protein of 233 amino acids. The cDNA sequence showed $68 \%$ identity and $73 \%$ query cover with other fungal gene sequences of which the function remains unknown. Escherichia coli containing the cloned gene secreted up to $567 \mathrm{mg} \cdot \mathrm{l}^{-1}$ acetic acid within $48 \mathrm{~h}$. The use of glucose, pyruvic acid, $\alpha$-ketoglutaric acid, and malic acid improved the acetic acid secretion of the E. coli $\mathrm{DH} 5 \alpha^{\mathrm{TM}}$ clone I-2. By contrast, the use of citric acid, succinic acid, and fumaric acid did not improve the acetic acid secretion of clone I-2 compared to a control $E$. coli DH5 $\alpha^{\mathrm{TM}}$ strain bearing only the cloning vector without any insert.

Conclusions. We obtained a novel gene from Penicillium oxalicum I1 whose overexpression in E. coli DH5 $\alpha^{\mathrm{TM}}$ increased the secretion of acetic acid. This observation should help to understand what is the function of the gene isolated from P. oxalicum as well as that of its homologs found in several other species of the Penicillium genus.

Keywords. Penicillium oxalicum, organic acids, cloning, gene banks.

Clonage d'un nouveau gène de Penicillium oxalicum I1 entrainant la sécrétion d'acide acétique chez Escherichia coli Description du sujet. Les acides organiques jouent un rôle essentiel dans la solubilisation de certains ions dans le sol. La surexpression hétérologue d'un gène unique au sein d'une cellule est une stratégie optimale pour accroitre la sécrétion d'acides organiques solubilisant le phosphate.

Objectifs. Lors de cette étude, nous avons élaboré une banque d'ADNc de Penicillium oxalicum I1. La capacité à solubiliser le phosphate d'un milieu au phosphate tricalcique (TCP) a été éprouvée pour les divers clones ainsi générés car via leur expression dans Escherichia coli, nous avons pu vérifier quels étaient ceux qui engendraient une augmentation de la sécrétion d'acides organiques. 
Méthode. Une banque primaire d'ADNc de Penicillium oxalicum I1 a été construite par le mécanisme du «template switching polymerase chain reaction ». La capacité d'E. coli $\mathrm{DH} 5 \alpha^{\mathrm{TM}}$ à sécréter des acides organiques par surexpression du gène du clone I-2 de P. oxalicum I1 a été éprouvée dans le milieu TCP comprenant le glucose comme seule source de carbone. Ensuite, on a substitué au glucose les acides pyruvique, citrique, $\alpha$-cétoglutarique, succinique, fumarique ou malique comme seule source de carbone du milieu TCP afin de vérifier à nouveau la capacité de sécrétion d'acides organiques des transformants d'E. coli $\mathrm{DH} 5 \alpha^{\mathrm{TM}}$.

Resultats. Un total de 106 clones testés a engendré un halo sur milieu TCP gélosé. Parmi ceux-ci, seul le clone I-2 a fourni un halo clair. L'ADNc du clone I-2 s'étend sur une longueur de 1151 pb et renferme une phase de lecture ouverte de $702 \mathrm{pb}$ codant pour une protéine hypothétique de 233 acides aminés. La séquence de l'ADNc présente une identité de $68 \%$ ainsi qu'un « query coverage » de $73 \%$ avec des séquences de gènes fongiques dont la fonction demeure inconnue. Le transformant d'E. coli DH5 $\alpha^{\mathrm{TM}}$ porteur du clone I-2 sécrète jusqu'à $567 \mathrm{mg} \cdot \mathrm{l}^{-1} \mathrm{~d}$ 'acide acétique en $48 \mathrm{~h}$. L'emploi de glucose ou des acides pyruvique, $\alpha$-cétoglutarique et malique comme seule source de carbone accroit la sécrétion d'acide acétique du transformant. À l'inverse, le recours aux acides citrique, succinique ou fumarique comme seule source de carbone n'améliore pas la sécrétion du clone I-2 comparé à un témoin porteur du seul vecteur pBluescript.

Conclusions. Nous avons mis en évidence un nouveau gène de P.oxalicum $\mathrm{I} 1$ dont la surexpression dans E. coli $\mathrm{DH} 5 \alpha^{\mathrm{TM}}$ peut entrainer un accroissement de la sécrétion d'acide acétique. Cette observation doit aider à cerner le rôle du gène isolé de P. oxalicum et de ses homologues identifiés dans d'autres espèces du genre Penicillium.

Mots-clés. Penicillium oxalicum, acide organique, clonage, banque de gènes.

\section{INTRODUCTION}

Many soil microorganisms can secrete organic acids, such as oxalic, lactic, acetic, propionic, malic, tartaric, citric, butyric, malonic, succinic, gluconic, and fumaric acids (Banik \& Dey, 1982; Altomare et al., 1999; Fomina et al., 2005; Khan et al., 2007; Bianco \& Defez, 2010; Gulati et al., 2010). These acids play important roles in agriculture by improving for instance phosphate solubilization and releasing metal ions to improve the concentration of plant essential nutrients (Dessureault-Rompré et al., 2007; Singh et al., 2007). Organic acids can chelate $\mathrm{Fe}^{3+}, \mathrm{Fe}^{2+}, \mathrm{Ca}^{2+}$, and $\mathrm{Al}^{3+}$, thereby converting insoluble forms of nutrients to soluble ones (Walpola \& Yoon, 2013). These acids could decrease fertilizer requirement and improve fertilizer utilization. However, they are scarcely found and the effects are limited in soil. Therefore, highly efficient expression of genes related to exogenous organic acid secretion for organic acid production is an optimal strategy for improving fertilizer utilization. In this strategy, the critical step is obtaining genes that can improve organic acid secretion and expressing these genes heterologously. Numerous studies on genes that can enhance organic acid secretion have been conducted. Genes in bacteria are primarily cloned to improve gluconic acid secretion (Goldstein et al., 1999). For example, pyrroloquinoline quinone genes from Enterobacter intermedium, Klebsiella pneumoniae, and Rahnella aquatilis have been expressed in Escherichia coli (Meulenberg et al., 1992; Kim et al., 1998; Kim et al., 2003). Few fungal genes demonstrate this function as well. Fungal genes have been expressed in E.coli to improve various organic acid secretions. Lü et al. (2012) cloned mitochondrial malate dehydrogenase from Penicillium oxalicum and expressed the gene in E. coli to improve malate, lactate, acetate, citrate, and oxalate secretions. Gong et al. (2014a) also cloned delta-1-pyrroline-5-carboxylate dehydrogenase from P.oxalicum and expressed the gene in $E$. coli to enhance the secretion of acetic acid and $\alpha$-ketoglutarate.

Penicillium oxalicum I1 is a fungus that secretes oxalic acid. In the current study, we constructed a primary cDNA library of P. oxalicum and screened clones that can solubilize phosphate in tricalcium phosphate (TCP) medium by clear halos. We aimed to obtain the gene expressed in E. coli that can enhance organic acid secretion.

\section{MATERIALS AND METHODS}

\subsection{Strains, plasmids, and media}

Penicillium oxalicum $\mathrm{I} 1$ was grown at $30{ }^{\circ} \mathrm{C}$ in potato dextrose agar medium. Plasmid transformants of $E$. coli $\mathrm{DH} 5 \alpha^{\mathrm{TM}}$ were grown at $37{ }^{\circ} \mathrm{C}$ in Luria-Bertani (LB) medium and TCP containing $100 \mu \mathrm{g} \cdot \mathrm{ml}^{-1}$ ampicillin. The TCP medium comprised the following (per liter of distilled water): glucose, $10 \mathrm{~g} ; 0.3 \mathrm{~g}$ of $\mathrm{MgSO}_{4} \cdot 7 \mathrm{H}_{2} \mathrm{O}$; $0.3 \mathrm{~g}$ of NaCl$; 0.3 \mathrm{~g}$ of KCl; $0.5 \mathrm{~g}$ of $\left(\mathrm{NH}_{4}\right)_{2} \mathrm{SO}_{4} ; 0.03 \mathrm{~g}$ of $\mathrm{FeSO}_{4} \cdot 7 \mathrm{H}_{2} \mathrm{O} ; 0.03 \mathrm{~g}$ of $\mathrm{MnSO}_{4} \cdot 4 \mathrm{H}_{2} \mathrm{O}$; and $5 \mathrm{~g}$ of $\mathrm{Ca}_{3}\left(\mathrm{PO}_{4}\right)_{2}, 15^{2} \mathrm{~g}$ of agar (liquid medium without agar) (Nautiyal, 1999). The vector used was pBluescript II SK(+) (TaKaRa, Japan). 


\subsection{Construction of cDNA library and screening for genes enhancing secretion of organic acid}

A cDNA library of P. oxalicum I1 was constructed using the SMART method. The cDNA sequences were linked to pBluescript II SK(+) and recombinant plasmids were transformed into competent E. coli $\mathrm{DH} 5 \alpha^{\mathrm{TM}}$ cells. Colonies diluted to 100 -fold were spread on TCP medium agar plates containing $100 \mu \mathrm{g}$. $\mathrm{ml}^{-1}$ ampicillin. Clear halos appeared after three days. These halos resulted from the solubilization of TCP by the clones secreting organic acid, and the clones were subcultured to confirm stability. The cDNA sequences were blasted in the GenBank database.

The open reading frame (ORF) was estimated based on the cDNA sequences translated into protein by DNAMAN V6.0. The ORF sequence was amplified with the sense (5'-TATTCGGAATTCATGCAG CCCTCCTACAATGT-3') and antisense (5'-CACGGACTCGAGCTATCGTGTCAAAT CTTTC CACAGA-3') primers.

The PCR mix contained $1 \mu \mathrm{M}$ of each primer, $10 \mu \mathrm{M}$ deoxynucleotide, 10× buffer (NEB, USA), and 1 unit of Taq Polymerase (NEB). This process was conducted under the following thermocycling conditions: initial denaturation at $94^{\circ} \mathrm{C}$ for $5 \mathrm{~min}$, followed by 35 cycles of $94{ }^{\circ} \mathrm{C}$ for $60 \mathrm{~s}, 60^{\circ} \mathrm{C}$ for $60 \mathrm{~s}, 72{ }^{\circ} \mathrm{C}$ for $60 \mathrm{~s}$, and a final elongation at $72{ }^{\circ} \mathrm{C}$ for $10 \mathrm{~min}$ (ABI 9700). The ORF sequence and pBluescript II SK(+) vector were digested with EcoRI and XhoI enzymes at $37{ }^{\circ} \mathrm{C}$ for $4 \mathrm{~h}$. Digested products were linked to pBluescript II SK(+) by T4 DNA ligase. Plasmids containing the ORF sequence were transformed into E. coli $\mathrm{DH} 5 \alpha^{\mathrm{TM}}$ competent cells. Transformants showing clear halos were selected from the TCP plates.

\subsection{Organic acid secretion}

The organic acid secretion ability of E. coli DH5 $\alpha^{\mathrm{TM}}$ with overexpressed P.oxalicum I1 gene was tested in liquid TCP medium. Escherichia coli DH5 $\alpha^{\mathrm{TM}}$ containing pBluescript II SK(+) and ORF sequence (pPos) or pBluescript II SK(+) (pBlu) were grown in TCP. An aliquot $(100 \mu 1)$ of each bacterial culture $\left(10^{8} \mathrm{cfu} \cdot \mathrm{ml}^{-1}\right)$ was grown in $50 \mathrm{ml}$ of broth. The culture was shaken at $120 \mathrm{rpm}$ at $37^{\circ} \mathrm{C}$. Changes in $\mathrm{pH}$ of the medium and organic acid concentrations were measured in the culture filtrates at $0,8,16,24$, 36 , and $48 \mathrm{~h}$. The $\mathrm{pH}$ of the medium was measured using a $\mathrm{pH}$ meter equipped with a glass electrode. The cell density of E. coli $\mathrm{DH} 5 \alpha^{\mathrm{TM}}$ was tested by plate counting at $24 \mathrm{~h}$ and $48 \mathrm{~h}$. Organic acids produced were determined at $48 \mathrm{~h}$ by an anion chromatographic system (ICS-3000, Dionex, USA). The experiment was performed three times.

\subsection{Substrate utilization}

Pyruvic acid, citric acid, $\alpha$-ketoglutaric acid, succinic acid, fumaric acid, and malic acid were used as sole carbon source substitutes for glucose in the TCP medium whose $\mathrm{pH}$ was adjusted to 7.0. An aliquot $(100 \mu \mathrm{l})$ of E. coli DH5 $\alpha^{\mathrm{TM}}$ containing pPos culture $\left(10^{8} \mathrm{cfu} \cdot \mathrm{ml}^{-1}\right)$ was grown in $50 \mathrm{ml}$ of broth. The culture was shaken at $120 \mathrm{rev} \cdot \mathrm{min}^{-1}$ at $37^{\circ} \mathrm{C}$. Organic acids produced were determined at $48 \mathrm{~h}$ by an anion chromatography system (ICS-3000, Dionex, USA). The experiment was performed three times.

\subsection{Statistical analysis}

Statistical analysis was conducted by using Analysis of Variance (ANOVA) statistical package for social sciences (SPSS) software, version 21.0 followed by comparison of multiple treatment levels with the control, using the significant difference (LSD) at $p \leq 0.05$.

\section{RESULTS}

\subsection{Screening for genes enhancing of secretion of organic acids}

Selection of the $E$. coli transformants with cDNA from P. oxalicum were tested on their ability to produce larger amounts of organic acid by checking the clear halos they induce on TCP agar plates because of the phosphate solubilization by the clones after $3 \mathrm{~d}$ of incubation at $37^{\circ} \mathrm{C}$. The titer of the primary cDNA library was $5.65 \times 10^{6} \mathrm{cfu} \cdot \mathrm{ml}^{-1}$ with a recombination rate of $99.15 \%$. A total of 106 positive clones were obtained, and the diameters of the clear halos ranged from $1.3 \mathrm{~mm}$ to $4.2 \mathrm{~mm}$. The diameter of the clear halo of the clone I-2 was $3.6 \mathrm{~mm}$. The full-length cDNA of the clone I- 2 was $1,151 \mathrm{bp}$, and this clone contained an ORF of $702 \mathrm{bp}$ (pPos). This ORF encoded a $25.41 \mathrm{kDa}$ polypeptide comprising 233 amino acids. The cDNA sequence was deposited to the GenBank under accession number JF419552.

The cDNA sequence was analyzed through the GenBank database. Pennicillium oxalicum I1 cDNA showed $68 \%$ identity and $73 \%$ query cover with Penicillium chrysogenum Wisconsin 54-1255 partial mRNA (accession number XM_002569279.1). The sequence from P. oxalicum I1 also showed $<66 \%$ identity and $53 \%$ query cover with other fungi. The deduced amino acid sequence of P. oxalicum I1 was analyzed using the Blast program (DNAMAN 6.0) via the GenBank database. Multiple alignment results revealed $100 \%$ identity between the amino acid sequences of P.oxalicum I1 and P.oxalicum 114-2 
(EPS25113.1), which has an unknown gene function. In addition, the sequence from P. oxalicum I1 can be aligned with hypothetical proteins of other closely related fungi (Figure 1). Even though for some the identity is below $63 \%$ identity, the alignment clearly shows that these hypothetical proteins belong to a same group that should share the same function.

\subsection{Organic acid secretion}

The subcloned ORF of the cDNA clone was inserted into pBluescript II SK(+), and the resulting recombinant plasmid pPos was transformed into E. coli $\mathrm{DH} 5 \alpha^{\mathrm{TM}}$. Clear halos resulting from TCP solubilization appeared in vitro. Finally, E. coli $\mathrm{DH} 5 \alpha^{\mathrm{TM}}$ containing the target gene was grown in TCP liquid medium to demonstrate the organic acid secretion ability of the recombinant. The $\mathrm{pH}$ values of the TCP liquid medium were more quickly reduced in $E$. coli bearing the cloned pPos (Figure 2a). The $\mathrm{pH}$ level decreased from $\mathrm{pH} 7.0$ to $\mathrm{pH} 3.57$ by pPos after $48 \mathrm{~h}$. Under the same condition, $\mathrm{pH}$ level decreased from $\mathrm{pH} 7.0$ to $\mathrm{pH} 5.41$ by $\mathrm{pBlu}$ (control E. coli $\mathrm{DH} 5 \alpha^{\mathrm{TM}}$ transformed with the pBluescript SK vector without any insert). However, the cell density of E. coli $\mathrm{DH} 5 \alpha^{\mathrm{TM}}$ was similar. The cell density of E. coli DH5 $\alpha^{\mathrm{TM}}$ with pPos was $37.67 \times 107,93.33 \times 10^{7} \mathrm{CFU}$.

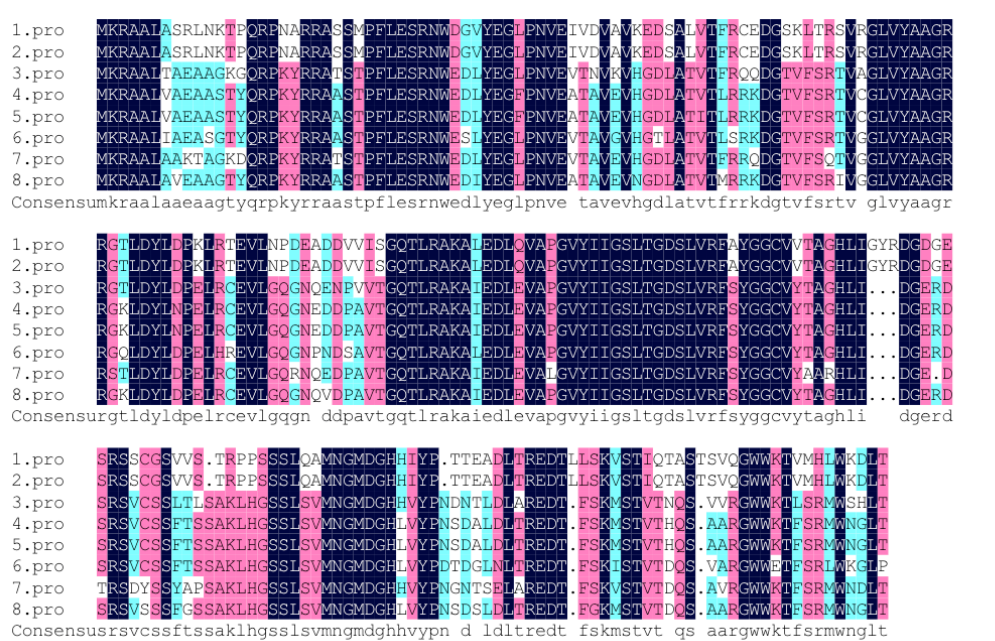

Figure 1. CLUSTALW alignment of the predicted amino acid sequence of the cloned Penicillium oxalicum I1 hypothetical protein with other Penicillium sp. hypothetical protein sequences deduced from DNA sequences reported in the GenBank database - Alignement obtenu par le logiciel CLUSTALW pour des séquences en acides aminés déduites du gène cloné de Penicillium oxalicum II et d'autres Penicillium sp. des séquences hypothétiques comparables déduites de séquences nucléotidiques de la banque de données GenBank.

1: Penicillium oxalicum I1; 2: Penicillium oxalicum 114-2 (EPS25113.1); 3: Penicillium roqueforti FM164 (CDM31604.1); 4: Penicillium expansum (KGO40648.1); 5: Penicillium expansum (KGO63351.1); 6: Penicillium digitatum PHI26 (EKV18840.1); 7: Penicillium rubens Wisconsin 54-1255 (XP_002569325.1); 8: Penicillium italicum (KGO74943.1).

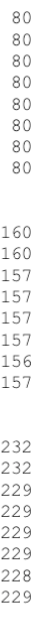

$\mathrm{ml}^{-1}$ at $24 \mathrm{~h}$ and $48 \mathrm{~h}$ respectively, and the cell density of E. coli $\mathrm{DH} 5 \alpha^{\mathrm{TM}}$ with pBlu was $21.33 \times 107,70.67 \mathrm{x}$ $10^{7} \mathrm{CFU} \cdot \mathrm{ml}^{-1}$ at $24 \mathrm{~h}$ and $48 \mathrm{~h}$ respectively.

We tested whether the decrease in $\mathrm{pH}$ in the presence of E. coli was correlated with organic acid secretion. Escherichia coli $\mathrm{DH} 5 \alpha^{\mathrm{TM}}$ (pPos and pBlu) secreted acetic acid, and the acetic acid concentration was $168.6 \mathrm{mg} \cdot \mathrm{l}^{-1}$ after $48 \mathrm{~h}$. However, the acetic acid concentration reached $567.3 \mathrm{mg} \cdot \mathrm{l}^{-1}$ by $E$. coli $\mathrm{DH} 5 \alpha^{\mathrm{TM}}$ (pPos), which was significantly higher than those from E. coli $\mathrm{DH} 5 \alpha^{\mathrm{TM}}$ (pBlu) (Figure $2 \mathbf{b}$ ).

\subsection{Substrate utilization}

Glucose, pyruvic acid, citric acid, $\alpha$-ketoglutaric acid, succinic acid, fumaric acid, and malic acid participate in the tricarboxylic acid cycle of E.coli $\mathrm{DH} 5 \alpha^{\mathrm{TM}}$. Escherichia coli $\mathrm{DH} 5 \alpha^{\mathrm{TM}}$ containing the target gene was grown in TCP liquid medium with one of the six organic acids as sole carbon sources instead of glucose to demonstrate the function of the cloned $\mathrm{pPos}$ sequence. The $\mathrm{pH}$ value significantly decreased and the acetic acid concentration increased with E.coli $\mathrm{DH} 5 \alpha^{\mathrm{TM}}$ bearing pPos compared to E. coli $\mathrm{DH} 5 \alpha^{\mathrm{TM}}$ (pBlu) in the TCP liquid medium after $48 \mathrm{~h}$ with glucose, pyruvic acid, $\alpha$-ketoglutaric acid, and malic acid. The acetic acid concentration reached $567.3,326.4$, 213.2 , and $225.3 \mathrm{mg} \cdot \mathrm{l}^{-1}$, respectively. No difference was found in the $\mathrm{pH}$ values and acetic acid contents between $E$. coli $\mathrm{DH} 5 \alpha^{\mathrm{TM}}$ (pPos) and E. coli DH5 $\alpha^{\mathrm{TM}}$ (pBlu) in TCP liquid medium with citric acid, succinic acid, and fumaric acid (Figure 3a and Figure 3b). The hypothetical protein could improve glucose, pyruvic acid, $\alpha$-ketoglutaric acid, and malic acid utilization in E. coli.

\section{DISCUSSION}

In this study, P. oxalicum I1 secreted a high amount of oxalic acid that reached $593.9 \mu \mathrm{g} \cdot \mathrm{ml}^{-1}$ at $30 \mathrm{~h}$ in culture, which decreased the $\mathrm{pH}$ of culture from 6.90 to 1.65 , and showed a strong ability to convert a wide range of insoluble phosphate into soluble forms (Gong et al., 2014b). Genes that can induce secretion of organic acids are present in the P.oxalicum I1 genome. Therefore $P$. oxalicum I1 was as a suitable organism from which to clone gene that may enhance organic acids secretion. From P. oxalicum I1, a total of 106 clones were obtained as candidates, and the 

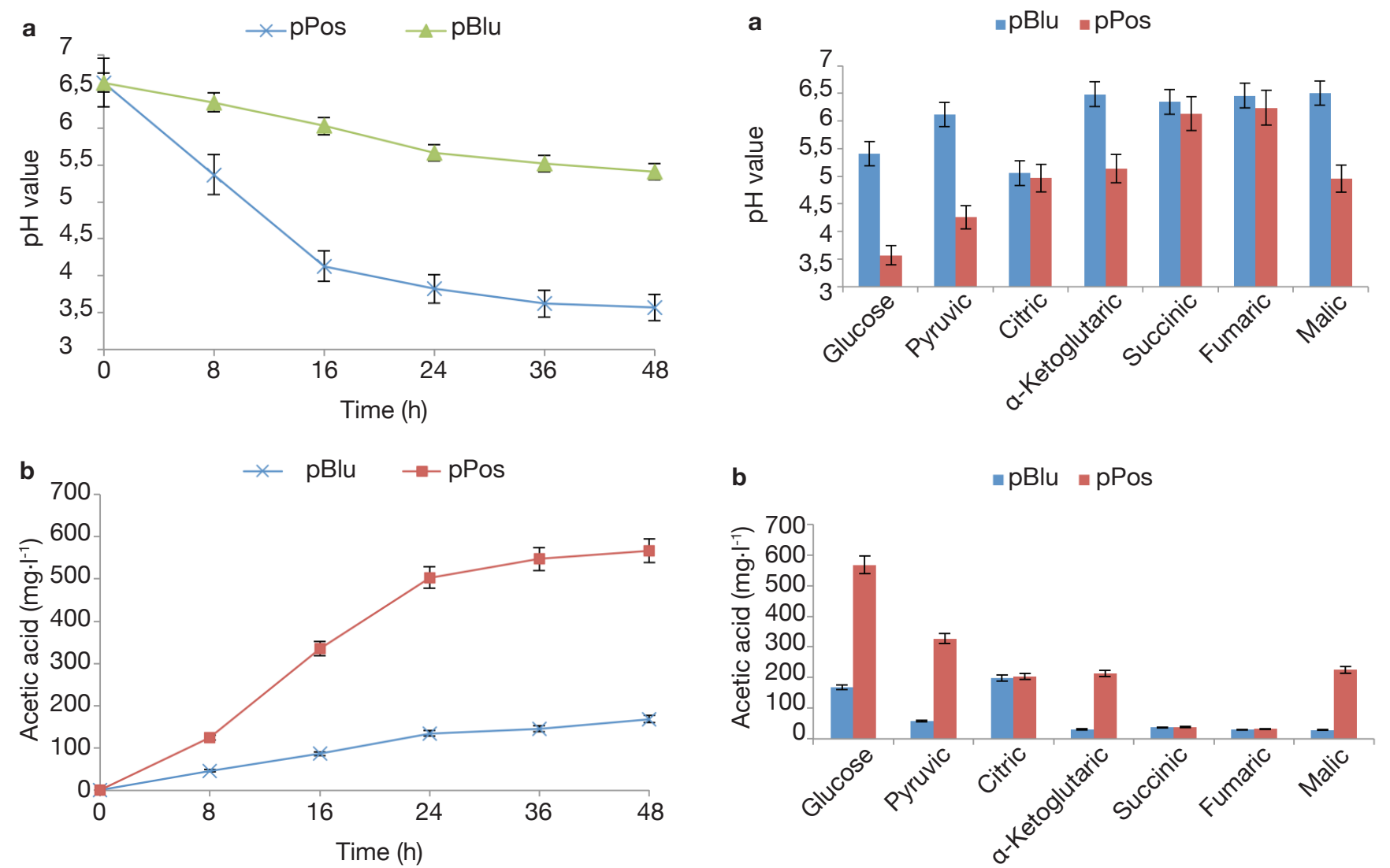

Figure 2. Changes in $\mathrm{pH}$ (a) or acetic acid concentration (b) of culture filtrates after Escherichia coli DH5 $\alpha$ was incubated in TCP liquid medium at $37^{\circ} \mathrm{C}-$ Évolution $d u$ $p H(\boldsymbol{a})$ et de la teneur en acide acétique (b) du filtrat de culture d'Escherichia coli DH5a incubée à $37{ }^{\circ} \mathrm{C}$ en milieu TCP liquide.

pBlu : E. coli DH5a transformed with pBluescript SK as a control - E. coli DH5 $\alpha$ transformé au moyen $d u$ plasmide pBluescript comme témoin; pPOS : E. coli $\mathrm{DH} 5 \alpha$ transformed with the recombinant plasmid in which pPOS was cloned - E. coli DH5a transformé au moyen du plasmide pBuescript SK dans lequel pPOS a été cloné; Data are means \pm $\mathrm{SD}-$ les valeurs sont les moyennes \pm écart-type.

cDNA sequence I-2 we obtained showed only $68 \%$ identity and $73 \%$ query cover with fungi. The deduced amino acid sequence showed $100 \%$ identity with a hypothetical protein in P. oxalicum 114-2, for which no gene function had been reported. The protein sequence from P. oxalicum I1 could be aligned with another hypothetical protein of the Penicillium genus. Even though for some alignments the identity is less than $63 \%$, it clearly forms a group of proteins that most probably share the same function. In this study, we proved that the protein can improve acetic acid secretion in E. coli $\mathrm{DH} 5 \alpha^{\mathrm{TM}}$. In addition, the E. coli DH5 $\alpha^{\mathrm{TM}}$ containing the target gene secreted up to $567 \mathrm{mg} \cdot \mathrm{l}^{-1}$ acetic acid within $48 \mathrm{~h}$. Lü et al. (2012)

Figure 3. $\mathrm{pH}$ (a), acetic acid concentration (b) of culture filtrates after Escherichia coli DH5 $\alpha$ was incubated for $48 \mathrm{~h}$ in TCP liquid medium with different substrates at $37{ }^{\circ} \mathrm{C}-p H(\boldsymbol{a})$ et teneur en acide acétique (b) d'un filtrat de culture d'Escherichia coli DH5 $\alpha$ incubé durant 48 h à $37^{\circ} \mathrm{C}$ sur milieu TCP liquide

pBlu, pPOS, data: see figure 2 - voir figure 2 .

cloned a full-length gene encoding mitochondrial malate dehydrogenase from $P$. oxalicum, which was expressed in E. coli to secrete malic, lactic, acetic, and citric acids, and the obtained amount of organic acids was $<60 \mathrm{mg} \cdot \mathrm{l}^{-1}$. Gong et al. (2014a) cloned the delta1-pyrroline-5-carboxylate dehydrogenase gene that secreted acetic acid and $\alpha$-ketoglutaric acids, and the obtained the acetic acid concentration was $389.81 \mu \mathrm{g}$. $\mathrm{ml}^{-1}$.

Many organic acid metabolic pathways, such as glycometabolism and tricarboxylic acid cycle, are also present in E. coli. Glucose, pyruvic acid, citric acid, $\alpha$-ketoglutaric acid, succinic acid, fumaric acid, and malic acid are the main substrates in the tricarboxylic acid cycle of E. coli DH5 $\alpha^{\mathrm{TM}}$. Escherichia coli DH5 $\alpha^{\mathrm{TM}}$ containing the target gene showed improved acetic acid secretion with the use of glucose, pyruvic acid, $\alpha$-ketoglutaric acid, and malic acid. By contrast, acetic acid secretion was not improved when citric acid, succinic acid, and fumaric acid were used. This result 
indicated that the hypothetical protein was related to the utilization of glucose, pyruvic acid, $\alpha$-ketoglutaric acid, and malic acid in E. coli.

\section{CONCLUSIONS}

We obtained a novel gene from Penicillium oxalicum I1 whose overexpression in E.coli $\mathrm{DH} 5 \alpha^{\mathrm{TM}}$ increased the secretion of acetic acid. Alignment of the putative amino acid sequence of the protein with other comparable sequences of the Penicillium genus suggests that this is a protein group sharing similar functions, nothing however is known about their role in the other organisms. The results reported here may help to understand the function of these genes and the corresponding protein group.

\section{Acknowledgements}

Project 41440008 supported by National Natural Science Foundation of China.

\section{Bibliography}

Altomare C., Norvell A., Björkman T. \& Harman G., 1999. Solubilization of phosphates and micronutrients by the plant growth promoting and biocontrol fungus Trichoderma harzianum Fifai 1295-22. Appl. Environ. Microbiol., 65, 2926-2933.

Banik S. \& Dey B., 1982. Available phosphate content of an alluvial soil as influenced by inoculation of some isolated phosphate-solubilizing micro-organisms. Plant Soil, 69, 353-364.

Bianco C. \& Defez R., 2010. Improvement of phosphate solubilization and medicago plant yield by an indole3-acetic acid-overproducing strain of Sinorhizobium meliloti. Appl. Environ. Microbiol., 76, 4626-4632.

Dessureault-Rompré J., Nowack B., Schulin R. \& Luster J., 2007. Spatial and temporal variation in organic acid anion exudation and nutrient anion uptake in the rhizosphere of Lupinus albus L. Plant Soil, 301, 123-134.

Fomina M. et al., 2005. Role of oxalic acid overexcretion in transformations of toxic metal minerals by Beauveria caledonica. Appl. Environ. Microbiol., 71, 371-381.

Goldstein A., Braverman K. \& Osorio N., 1999. Evidence for mutualism between a plant growing in a phosphatelimited desert environment and a mineral phosphate solubilizing (MPS) rhizobacterium. FEMS Microbiol. Ecol., 30, 295-300.

Gong M., Tang C. \& Zhu C., 2014a. Cloning and expression of delta-1-pyrroline-5-carboxylate dehydrogenase in Escherichia coli DH5 $\alpha$ improves phosphate solubilization. Can. J. Microbiol., 60(11), 761-765.

Gong M., Du P., Liu X. \& Zhu C., 2014b. Transformation of inorganic $\mathrm{P}$ fractions of soil and plant growth promotion by phosphate-solubilizing ability of Penicillium oxalicum I1. J. Microbiol., 52, 1012-1019.

Gulati A. et al., 2010. Organic acid production and plant growth promotion as a function of phosphate solubilization by Acinetobacter rhizosphaerae strain BIHB 723 isolated from the cold deserts of the transHimalayas. Arch. Microbiol., 192, 975-983.

Khan M., Zaidi A. \& Wani P., 2007. Role of phosphatesolubilizing microorganisms in sustainable agriculture - A review. Agron. Sustain. Dev., 27, 2943.

Kim C. et al., 2003. Cloning and expression of pyrroloquinoline quinine (PQQ) genes from a phosphatesolubilizing bacterium Enterobacter intermedium. Curr. Microbiol., 47, 457-461.

Kim K., Jordan D. \& Krishnan H., 1998. Expression of genes from Rahmella aquatilis that are necessary for mineral phosphate solubilization in Escherichia coli. FEMS Microbiol. Lett., 159, 121-127.

Lü J., Gao X., Dong Z. \& An L., 2012. Expression of mitochondrial malate dehydrogenase in Escherichia coli improves phosphate solubilization. Ann. Microbiol., 62, 607-614.

Meulenberg J. et al., 1992. Nucleotide sequence and structure of the Klebsiella pneumonia pqq operon. Mol. Gen. Genet., 232, 284-294.

Nautiyal C., 1999. An efficient microbiological growth medium for screening phosphate solubilizing microorganisms. FEMS Microbiol. Lett., 182, 265-270.

Singh K.P., Suman A., Singh P.N. \& Lal M., 2007. Yield and soil nutrient balance of a sugarcane plant-ratoon system with conventional and organic nutrient management in sub-tropical India. Nutr. Cycl. Agroecosyst., 79, 209-219.

Walpola B. \& Yoon M., 2013. Phosphate solubilizing bacteria: assessment of their effect on growth promotion and phosphorous uptake of mung bean (Vigna radiata (L.) R. Wilczek). Chil. J. Agric. Res., 73, 275-281.

(17 ref.) 